\title{
Ethylene and its inhibitors affect the quality of processed sweet potatoes
}

\author{
Paula Cristina Carvalho LIMA ${ }^{1 \dagger}$ (D), Mirelle Nayana de Sousa SANTOS ${ }^{\star *}$, Maria Eduarda da Silva GUIMARÃES ${ }^{1}$, \\ Nícolas Oliveira de ARAÚJO ${ }^{1}$, Marcelo Rodrigo KRAUSE ${ }^{1}$, Fernando Luiz FINGER ${ }^{1}$
}

\begin{abstract}
Sweet potato fried chips have great acceptance and high market value. Sprouting and fresh mass loss of tuberous roots during storage compromise the quality of the processed products. The objective of this work was to evaluate the effect of 1-Methylcyclopropene (1-MCP), amino-oxyacetic acid (AOA), and ethylene on the physico-chemical quality of fresh sweet potato and its relationship with fried color score in processed chips of cv. BRS Rubissol stored at room temperature. During storage, the weight loss, sprouts number, dry matter content, non-enzymatic browning, protein content, soluble phenols fraction, reducing sugars, total amino acids, $\mathrm{pH}$, soluble solids (SS), titratable acidity (TA) and SS/TA ratio were evaluated. The sweet potato roots cv. BRS Rubissol present good potential for processing as fried chips. 1-MCP and AOA treatments reduced the root sprouting, physico-chemical quality was maintained in all treatments and the fried chips showed less browning in all treatments with storage. Since the sprouting process compromises the storage of roots, AOA and 1-MCP treatments may be applied to extend the shelf-life of roots and improve the processing potential.
\end{abstract}

Keywords: amino acids; carbohydrates; fried foods; Ipomoea batatas; storage.

Practical Application: Ethylene and its inhibitors can act in sprout control of sweet potato roots stored at room temperature, contribute to the sweet potato production chain for processing. This research could help producers, in addition to contributing to the sweet potato processing industry, generating knowledge and information that could be inserted into an alternative method to control sprouting and increasing the quality of the processed product.

\section{Introduction}

Sweet potatoes roots (Ipomoea batatas Lam) have become the focus of research in recent years due to their unique nutritional and functional properties (Wang et al., 2016). Sweet potato has been identified as an important nutritious food, because contains reasonable amounts of bioactive compounds such as $b$-carotene, ascorbic acid, polyphenols, dietary fibre as well as vitamins, minerals, and proteins (Motsa et al., 2015).

According to the statistics from the Food and Agriculture Organization of the United Nations (Food and Agriculture Organization, 2016), the world's total production of sweet potatoes in 2016 was 105 million tons, occupying the sixth-largest crop in comparison to other staple foods crops. In 2016, Brazil produced 0.67 million tons of sweet potatoes, accounting for $0.64 \%$ of the world's total production $(\mathrm{Mu} \mathrm{\&} \mathrm{Li}, 2019)$. Sweet potato cv. BRS Rubissol yields on average 40 tonnes per hectare and presents quality for industrial processing (Castro \& Becker, 2011); however, when the roots are stored at room temperature the shelf life is over in two to four weeks due to sprouting and only a limited number of works were done on the control root sprouting.

During sprouting events a highly dynamic hormonal crosstalk takes place, affected by endogenous factors related to development and cellular and tissue specificity (Van de Poel et al., 2015).
Ethylene regulates many physiological and biochemical mechanisms affecting the quality of the horticultural products, and continuous exposure to ethylene can be an alternative for potato and sweet potato sprout control (Amoah et al., 2016; Cheema et al., 2013).

1-Methylcyclopropene (1-MCP) competes with ethylene for the binding sites, inhibiting the action and delaying the ethylene-dependent responses. 1-MCP has been widely applied in several climacteric fruits to delay ripening and in vegetables to reduce the deleterious effects of ethylene (Watkins, 2006; $\mathrm{Xu}$ et al., 2016). Also, 1-MCP treatment can delay sprouting in stored potatoes and sweet potatoes (Cheema et al., 2013; Lima et al., 2019).

Amino-oxyacetic acid (AOA) inhibits 1-carboxylic acid-1-aminocyclopropane synthase (ACC synthase), considered a limiting enzyme of ethylene biosynthesis, due to the competition for binding with pyridoxamine 5'-phosphate on the active site of the enzyme (Mathooko et al., 2001). Aminoethoxyvinylglycine (AVG) treatment delays sprouting in sweet potatoes (Cheema et al., 2013; Lima et al., 2019), since AOA has a similar mechanism of action to AVG, suggesting that could also have a similar effect.

Snacks are sold as either a packaged snack or processed with an extremely important position in the market of food. 
They meet the consumption habits and fashion of modern life habits attracting consumers for their good color, flavor, and taste (Mu et al., 2019). However, in fried starchy products, there is potential contaminant residue that affects consumers and the industry, like acrylamide that is a contaminant formed during frying. The presence of acrylamide in processed foods is considered one of the most important problems for the food industry (Muttucumaru et al., 2017), due to its carcinogenic effects (Truong et al., 2014).

The objective of this work was to evaluate the effect of 1-MCP, AOA, and ethylene treatments on the physico-chemical quality of fresh and chips fried color of sweet potato roots $\mathrm{cv}$. BRS Rubissol stored at room temperature.

\section{Materials and methods}

\subsection{Plant material and experimental area characterization}

Sweet potato seedlings of cv. BRS Rubissol were acquired from Frutplan (Pelotas, Rio Grande do Sul, Brasil). The crop was cultivated following standard commercial practices by applying 100 g. $\mathrm{m}^{2}$ of limestone, 100 g.m $\mathrm{m}^{2}$ of NPK 8-28-16 after planting, and 50 g.m ${ }^{2}$ of NPK 8-28-16 at every 30 days for six months. The experiment was conducted at the experimental field in

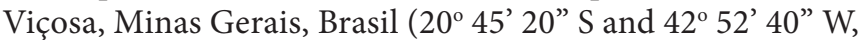
$651 \mathrm{~m}$ a.s.1.).

\subsection{Harvesting and curing of roots}

The harvest was done manually and roots free of apparent damage and disease were standardized by mass between $300-700 \mathrm{~g}$. Roots were cured in the germination chamber at $30{ }^{\circ} \mathrm{C}$ and $90 \%$ relative humidity for 7 days (Amoah et al., 2016).

\subsection{Experimental procedures}

The treatments followed the guidelines proposed by Cheema et al. (2013) with adaptations as follow: control (air), fumigation with $1 \mathrm{mg} . \mathrm{L}^{-1}$ of 1-MCP SmartFresh" (Rohm and Haas, Pensilvânia, EUA) in $90 \mathrm{~L}$ sealed chamber for 24 hours, the immersion of the roots in $1 \mathrm{mg} . \mathrm{L}^{-1}$ of AOA solution (Sigma-Aldrich, Missouri, EUA) for 1 hour and subsequent drying with absorbent paper and injection of $10 \mu \mathrm{L} . \mathrm{L}^{-1}$ of ethylene in $90 \mathrm{~L}$ sealed chamber for 48 hours. Afterward, the roots were stored in germination chambers at $25^{\circ} \mathrm{C}$ and $90 \%$ relative humidity.

\subsection{Physical analysis}

Weight loss was determined in an analytical balance of $1200 \mathrm{~g}$ with an accuracy of $0.1 \mathrm{~g}$ (Bel Engineering M1003), the results were expressed in percentage, according to Equation 1:

Weight loss $(\%)=\frac{W 0-W f}{W 0} \times 100$

Where $W_{0}$ was the initial weight of samples, and $W_{\mathrm{f}}$ was the weight loss of the samples after each storage time.
Sprouts number was determined considering those bigger than $1 \mathrm{~mm}$ in length, the evaluation was completed using a digital calipter and the results were expressed as the number of sprouts per root.

The dry matter content was determined in fresh sweet potato roots cleaned and chopped into small pieces, $5 \mathrm{~g}$ was dried in a forced-air ventilation oven at $60{ }^{\circ} \mathrm{C}\left( \pm 3{ }^{\circ} \mathrm{C}\right)$ and $0.5 \mathrm{~m} . \mathrm{s}^{-1}$ air velocity, until reaching constant mass, the results were expressed in percentage on a fresh weight basis.

Non-enzymatic browning or browning index was determined from sweet potato chips color after frying, the roots peeled and processed as 2 -mm-thick chips, and rinsed for $2 \mathrm{~min}$ in $0.2 \%$ sodium bisulfite solution to prevent enzymatic browning. The chips were dried with absorbent paper and fried in refined soybean oil for $2 \mathrm{~min}$ at $180^{\circ} \mathrm{C}$ (Caetano et al., 2018) in an electric fryer (Ford, Michigan, EUA). Color analysis was based on the following scale of scores: 1 , chips with no surface browning; 2 , chips with up to $25 \%$ browning surface, 3 , chips with up to 26 to $50 \%$ of browning surface, 4 , chips with up to $51-75 \%$ of browning surface; 5 , chips with more than $75 \%$ of browning surface.

\subsection{Biochemical analyzes}

Total protein content from the flesh of roots was determined by the Bradford method (Bradford, 1976), using bovine serum albumin $0.001 \%$ as the standard. The reading was done in Genesys 10S UV-VIS spectrophotometer (Thermo Scientific, Massachusetts, EUA) at $595 \mathrm{~nm}$ and the results were expressed as mg. $100 \mathrm{~g}^{-1} \mathrm{FW}$.

Soluble phenols fraction from the flesh of roots was determined from the ethanolic extract by the Follin-Ciocalteu method (Fu et al., 2010), using gallic acid $0.0125 \%$ as the standard solution. The reading was done in Genesys 10S UV-VIS spectrophotometer (Thermo Scientific, Massachusetts, EUA) at $760 \mathrm{~nm}$ and the results were expressed as mg gallic acid. $100 \mathrm{~g}^{-1} \mathrm{FW}$.

Reducing sugars from the flesh of roots were extracted with ethanol $80 \%$ and quantified by the dinitrosalicylic acid method as described by Gonçalves et al. (2010), with some alterations, using $0.2 \%$ fructose as the standard solution. The reading was done on Genesys 10S UV-VIS spectrophotometer at $540 \mathrm{~nm}$ and the results were expressed as mg fructose. $100 \mathrm{~g}^{-1} \mathrm{FW}$.

Amino acid content from the flesh of roots was determined using ninhydrin reagent assay (Yemm et al., 1955). For quantification, $0.0075 \%$ glycine was used as the standard solution. The reading was done on a Genesys 10S UV-VIS spectrophotometer at $570 \mathrm{~nm}$ and the results were expressed as mg glycine. $\mathrm{g}^{-1} \mathrm{FW}$.

\subsection{Physicochemical analysis}

Soluble solids from the flesh of roots was determined in a digital refractometer (Hanna Instruments HI 96801), the results were expressed in ${ }^{\circ}$ Brix (Association of Official Analytical Chemists, 2012) and $\mathrm{pH}$ was measured in a bench $\mathrm{pH}$ meter (Digimed DM-22) (Association of Official Analytical Chemists, 2012). Titratable acidity from the flesh of roots was determined by titration with a standard solution of $0.1 \mathrm{M}$ sodium hydroxide until the sample reaches $\mathrm{pH}$ 8.1. The results were expressed 
in g citric acid. $100 \mathrm{~g}^{-1} \mathrm{FW}$ (Association of Official Analytical Chemists, 2012) and soluble solids/titratable acidity (SS/TA) ratio was determined by the ratio of the two variables.

\subsection{Statistical analysis}

The experiment was set up as a completely randomized design in a split-plot arrangement. The plots consisted of four treatments (control, 1-MCP, AOA, and ethylene), whereas the subplots were represented by the storage length $(0,7,14,21,28$ and 35 days). Data were subjected to analysis of variance, with the storage time and treatment evaluated factors levels were compared by Tukey test at $5 \%$ probability. Statistical analyzes were carried out using statistical software Sisvar (Ferreira, 2011) and the graph design was made in SigmaPlot 10.0 software. Pearson's correlations between variables were performed using the R 'corrplot' package (Wei et al., 2017).

\section{Results and discussion}

In Table 1, the weight loss showed increases in all treatments during storage, but showed reductions of 13 and $18 \%$ in $1-\mathrm{MCP}$ and AOA treatments, respectively, when compared to control. The sprout number was lower for the roots treated with 1-MCP and AOA showing reductions of 69 and $70 \%$, respectively, when compared to control. Control roots showed the highest average number of sprouts along the storage, followed by ethylene treatment, whereas there was no statistical differences for the $1-\mathrm{MCP}$ and AOA treatments (Table 1).

The low values of weight loss are probably due to the root curing process, but was related to the incidence of sprouting, because respiration and evaporation increase rapidly with the onset of sprouting and continuous sprout growth, resulting in a rapid increase in mass loss of stored roots and impairing the nutritional status and quality aspects of products (Mani et al., 2014). Cheema et al. (2013) also observed relationships between mass loss and sprouting when evaluating sweet potato roots of cultivars 'Bushbuck' and 'Ibees', showing higher fresh mass losses and a number of sprouts in control, and lower in 1-MCP treatment.

The effects of ethylene accumulation on cell division and cell expansion can be either positive or negative, depending on the environmental context and the organ (Dubois et al, 2018). In this case, the use of ethylene inhibitors was efficient in inhibiting sprouting, because ethylene regulates some processes related to cell stretching, as cytoskeletal rearrangement, cell wall relaxation, and water uptake to establish turgor pressure (Van de Poel et al., 2015).

Dry matter content of roots did not differ among treatments or storage length (Table 1). Products with high dry matter result in a high-quality product for processing (Caetano et al., 2018). The results showed values above $20 \%$, indicating that the roots are proper for frying. The high dry mass content $(>20 \%)$ reduces

Table 1. Weight loss (\%), sprouts number per root, dry matter content (\%), and non-enzymatic browning (browning index - 1-5) in sweet potato roots (BRS Rubissol) stored at $25^{\circ} \mathrm{C}$, according to the applied treatment.

\begin{tabular}{|c|c|c|c|c|c|c|}
\hline & Day 0 & Day 7 & Day 14 & Day 21 & Day 28 & Day 35 \\
\hline Treatments & \multicolumn{6}{|c|}{ Weight loss } \\
\hline Control & $0.00 \pm 0.00 \mathrm{aD}^{*}$ & $1.27 \pm 0.14 \mathrm{aD}$ & $2.96 \pm 0.19 \mathrm{aC}$ & $3.88 \pm 0.20 \mathrm{aBC}$ & $5.22 \pm 0.36^{\mathrm{aAB}}$ & $6.58 \pm 0.75^{\mathrm{aA}}$ \\
\hline $\mathrm{AOA}$ & $0.00 \pm 0.00 \mathrm{aE}$ & $0.08 \pm 0.00 \mathrm{aDE}$ & $2.38 \pm 0.11^{\mathrm{aCD}}$ & $3.12 \pm 0.19^{\mathrm{bBC}}$ & $4.23 \pm 0.29^{\mathrm{bAB}}$ & $5.35 \pm 0.33^{\mathrm{aA}}$ \\
\hline Ethylene & $0.00 \pm 0.00^{\mathrm{aE}}$ & $1.41 \pm 0.08^{\mathrm{aDE}}$ & $2.65 \pm 0.19^{\mathrm{aCD}}$ & $3.61 \pm 0.23^{\mathrm{abBC}}$ & $5.09 \pm 0.38^{\mathrm{abAB}}$ & $6.19 \pm 0.37^{\mathrm{aA}}$ \\
\hline Control & $0.00 \pm 0.00 \mathrm{aC}^{*}$ & $5.44 \pm 1.19^{\mathrm{aBC}}$ & $7.72 \pm 1.55^{\mathrm{aABC}}$ & $9.35 \pm 2.06^{\mathrm{aABC}}$ & $13.58 \pm 2.87^{\mathrm{aAB}}$ & $19.71 \pm 2.50^{\mathrm{aA}}$ \\
\hline 1-MCP & $0.00 \pm 0.00^{\mathrm{aA}}$ & $0.85 \pm 0.30^{\mathrm{bcA}}$ & $1.09 \pm 0.38 \mathrm{bcA}$ & $1.81 \pm 0.49 \mathrm{bcA}$ & $2.82 \pm 0.80^{\mathrm{bA}}$ & $5.33 \pm 1.39^{\mathrm{bA}}$ \\
\hline $\mathrm{AOA}$ & $0.00 \pm 0.00^{\mathrm{aA}}$ & $0.00 \pm 0.00^{\mathrm{cA}}$ & $0.48 \pm 0.23^{\mathrm{cA}}$ & $0.87 \pm 0.36^{\mathrm{cA}}$ & $2.18 \pm 0.69^{\mathrm{bA}}$ & $5.20 \pm 1.63^{\mathrm{bA}}$ \\
\hline \multirow[t]{2}{*}{ Ethylene } & $0.00 \pm 0.00^{\mathrm{aB}}$ & $4.11 \pm 0.91^{\mathrm{abAB}}$ & $5.14 \pm 1.24^{\mathrm{abAB}}$ & $5.87 \pm 1.38^{\mathrm{abAB}}$ & $8.45 \pm 2.43^{\mathrm{aAB}}$ & $15.83 \pm 2.76^{\mathrm{aA}}$ \\
\hline & \multicolumn{6}{|c|}{ Dry matter content } \\
\hline $\mathrm{AOA}$ & $25.58 \pm 2.12^{\mathrm{aA}}$ & $24.83 \pm 3.14^{\mathrm{aA}}$ & $28.92 \pm 1.36^{\mathrm{aA}}$ & $28.69 \pm 1.24^{\mathrm{aA}}$ & $26.67 \pm 1.52^{\mathrm{aA}}$ & $28.16 \pm 1.32^{\mathrm{aA}}$ \\
\hline \multirow[t]{2}{*}{ Ethylene } & $25.58 \pm 2.12^{\mathrm{aA}}$ & $25.26 \pm 1.28^{\mathrm{aA}}$ & $24.75 \pm 2.31^{\mathrm{aA}}$ & $27.54 \pm 1.74^{\mathrm{aA}}$ & $26.92 \pm 1.43^{\mathrm{aA}}$ & $28.16 \pm 2.50^{\mathrm{aA}}$ \\
\hline & \multicolumn{6}{|c|}{ Non-enzymatic Browning } \\
\hline Control & $4.54 \pm 0.08^{\mathrm{aA}^{*}}$ & $4.29 \pm 0.08^{\mathrm{aA}}$ & $3.42 \pm 0.14^{\mathrm{bB}}$ & $2.12 \pm 0.14^{\mathrm{aC}}$ & $2.16 \pm 0.14^{\mathrm{abC}}$ & $1.37 \pm 0.08^{\mathrm{cD}}$ \\
\hline 1-MCP & $4.54 \pm 0.08^{\mathrm{aA}}$ & $4.25 \pm 0.06^{\mathrm{aA}}$ & $3.50 \pm 0.18^{\text {ьв }}$ & $2.21 \pm 0.19^{\mathrm{aC}}$ & $2.46 \pm 0.08^{a b C}$ & $1.95 \pm 0.15^{\mathrm{abC}}$ \\
\hline $\mathrm{AOA}$ & $4.54 \pm 0.08^{\mathrm{aA}}$ & $4.33 \pm 0.08^{\mathrm{aAB}}$ & $3.96 \pm 0.15^{\mathrm{aB}}$ & $2.33 \pm 0.18^{\mathrm{aC}}$ & $2.58 \pm 0.12^{\mathrm{aC}}$ & $2.08 \pm 0.10^{\mathrm{aC}}$ \\
\hline Ethylene & $4.54 \pm 0.08{ }^{\mathrm{aA}}$ & $4.29 \pm 0.08^{\mathrm{aA}}$ & $3.54 \pm 0.12$ abB & $2.08 \pm 0.17^{\mathrm{aC}}$ & $2.12 \pm 0.18$ bC & $1.54 \pm 0.10^{\mathrm{bcD}}$ \\
\hline
\end{tabular}

${ }^{*}$ Means followed by the same lowercase letter don't differ from each other in the same column, and means followed by the same capital letter don't differ from each other on the same line. Means were compared by the Tukey test $(\mathrm{p}<0.5)$. The standard error of the mean is shown $(\mathrm{n}=5)$. 
fat absorption during frying, being responsible for the highest yield and quality of the final product and is positively related to the texture, taste and overall quality of the chips (Müller et al., 2009).

Non-enzymatic browning was lower for the control and roots treated with ethylene, accounting for 1.37 and 1.54, respectively at the 35 days of storage. Regardless the treatment, the chips had less browning along the storage (Table 1). These reductions indicate less Maillard reaction compared to the beginning of storage (Figure 1).

Biochemical and nutritional changes during food processing and storage have important implications for both consumer protection and health as well as food quality (Orlien \& Bolumar, 2019). Color is fundamental in the judgment of quality by the consumer, chips with a clear golden color, and no dark spots return a high market price. According to Meher et al. (2015) the operating conditions (chips diameter, moisture content before frying and pre-drying temperature), of drying at a moisture content of $200(\% \mathrm{db})$, temperature of $60^{\circ} \mathrm{C}$ and frying at $170{ }^{\circ} \mathrm{C}$ for $180 \mathrm{~s}$, results in the best quality sweet potato chips.

Total protein content of roots did not differ among treatments or length of storage (Table 2), but the averages showed reductions over the storage period, showing mobilization of reserves for the sprouting process. Sweet potato contains approximately $1.73-9.14 \%$ of protein on a dry weight basis. Sweet potato protein is mainly composed of sporamins, which are rich in essential amino acids, been comparable with other superior quality vegetable proteins (Mu et al., 2009).

In Table 2, you can see the results of soluble phenols fraction did not differ among treatments treatment, but showed significant variations only in the control roots, showing higher averages at
14 days of storage and then reductions afterward. Soluble phenols are secondary metabolites that provide important functional attributes for plants, involved in quality characteristics such as taste and appearance (Abbasi et al., 2015). The stability of soluble phenols fraction was also observed by Amoah et al. (2016) which showed little variation in relation to the soluble phenols in the distal region of flesh of sweet potato roots stored for up to 30 days at $25^{\circ} \mathrm{C}$.

Reducing sugars content did not differ among treatments or storage length (Table 2), but the averages showed reductions over the storage length. The lowest values are shown in the control and ethylene treatment, due to a higher incidence of sprouting, which results in increased respiration and higher consumption of monosaccharides. The data corroborate the Cheema et al. (2013), wherein 1-MCP and AVG treatments, with or without ethylene, showed higher concentrations of monosaccharides than sweet potato roots cv. 'Bushbuck' stored at room temperature treated only with ethylene.

The amino acid content did not differ among treatments. Nevertheless showed significant reductions in all treatments during storage. These reductions may be related to the mobilization of energy reserves for sprouts growth, biosynthetic processes, and senescence (Table 2).

Since there are many mechanisms for the oxidation of proteins, free amino acids, and small peptides are quickly diverted protein synthesis and enter the catabolic route. Glutamate dehydrogenase is an enzyme responsible for the oxidation of amino acids, providing energy for the Krebs Cycle and/or reduction of a-ketoglutarate for the synthesis of new amino acids to be used as an energy source (Santos et al., 2005).

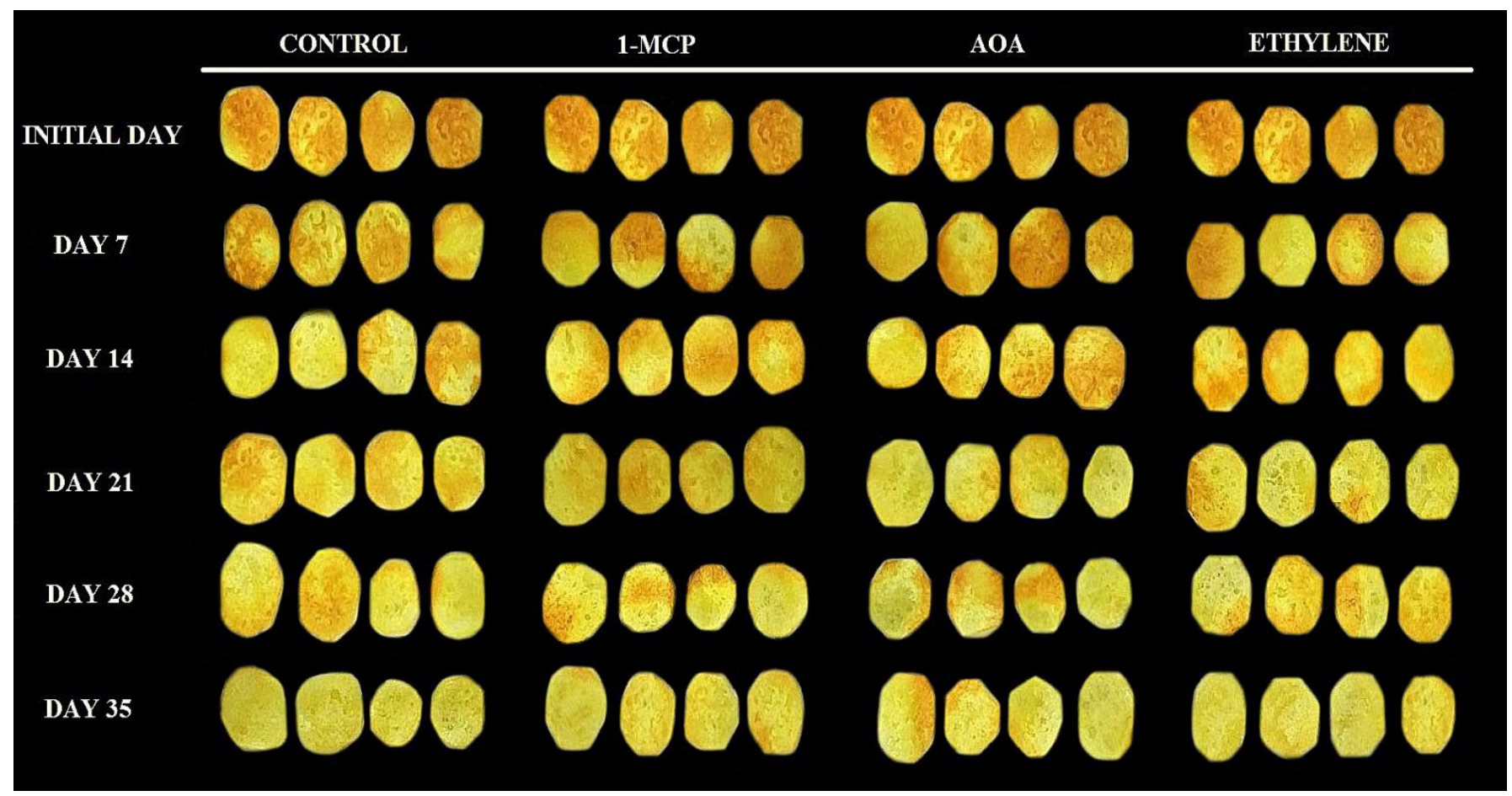

Figure 1. Visual analysis of sweet potato chips (BRS Rubissol) stored at $25^{\circ} \mathrm{C}$, according to applied treatments and storage time. 
Lima et al.

Table 2. Total protein content (mg.100-1 FW), soluble phenols fraction (mg gallic acid. $\left.100 \mathrm{~g}^{-1} \mathrm{FW}\right)$, reducing sugars content (mg.100 $\left.{ }^{-1} \mathrm{FW}\right)$ and amino acids content (mg.100 g $\mathrm{g}^{-1} \mathrm{FW}$ ) soluble in sweet potato roots (BRS Rubissol) stored at $25^{\circ} \mathrm{C}$, according to the applied treatment.

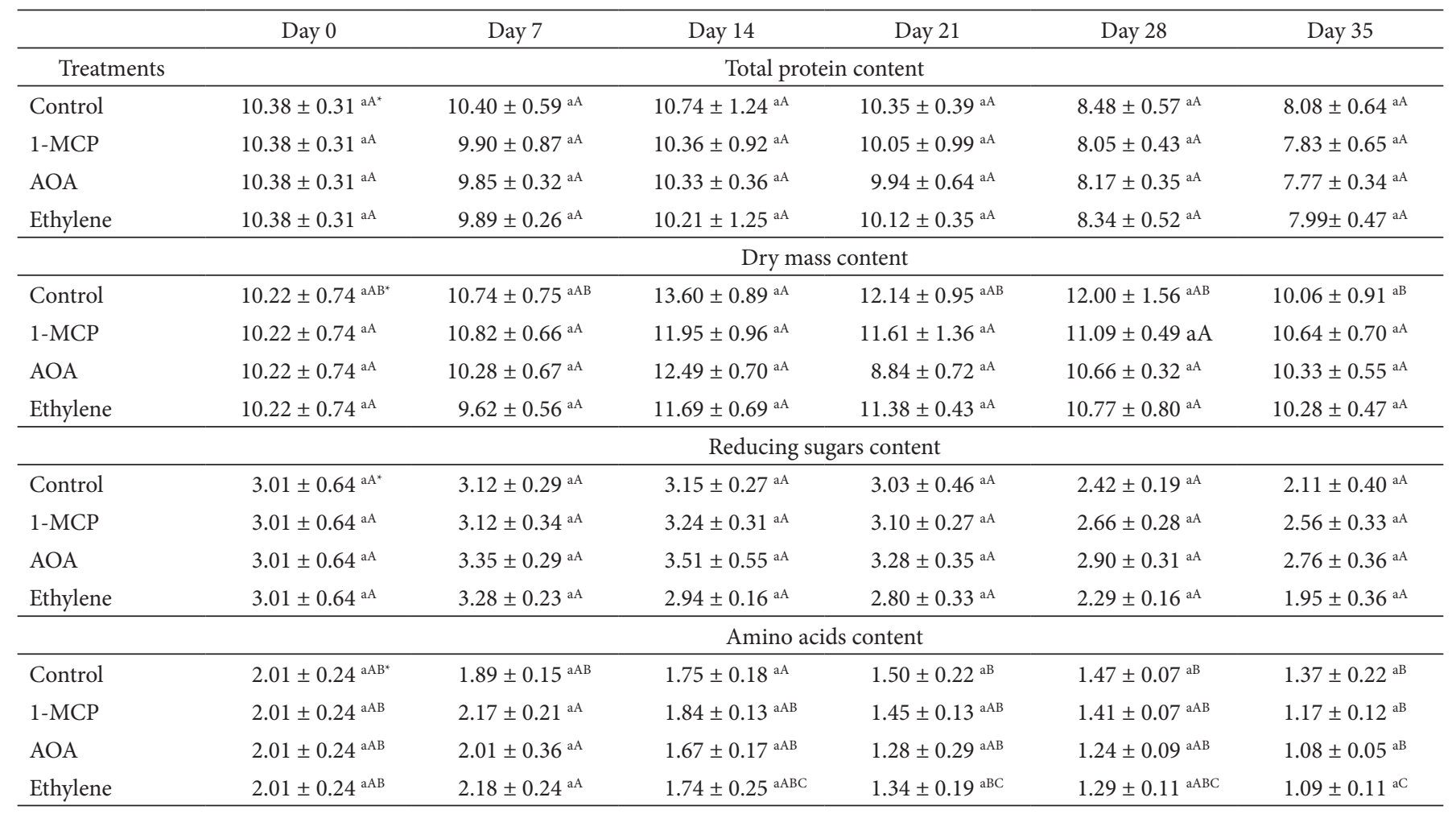

${ }^{*}$ Means followed by the same lowercase letter don't differ from each other in the same column, and means followed by the same capital letter don't differ from each other on the same line. Means were compared by Tukey test $(\mathrm{p}<0.5)$. The standard error of the mean is shown $(n=5)$.

Table 3. PH, soluble solids ( ${ }^{\circ}$ Brix), titratable acidity ( $\mathrm{mg}$ citric acid. $100 \mathrm{~g}^{-1} \mathrm{FM}$ ) and soluble solids/titratable acidity ratio (SS/TA ratio) in sweet potato roots (BRS Rubissol) stored at $25^{\circ} \mathrm{C}$, according to the applied treatment.

\begin{tabular}{|c|c|c|c|c|c|c|}
\hline & Day 0 & Day 7 & Day 14 & Day 21 & Day 28 & Day 35 \\
\hline Treatments & \multicolumn{6}{|c|}{$\mathrm{pH}$} \\
\hline Control & $6.70 \pm 0.04^{\mathrm{aA}^{*}}$ & $6.63 \pm 0.08^{\mathrm{aAB}}$ & $6.49 \pm 0.03^{\mathrm{aB}}$ & $6.18 \pm 0.05^{\mathrm{bC}}$ & $6.19 \pm 0.03^{\mathrm{aC}}$ & $6.23 \pm 0.03^{\mathrm{aC}}$ \\
\hline $\mathrm{AOA}$ & $6.70 \pm 0.04^{\mathrm{aA}}$ & $6.65 \pm 0.06^{\mathrm{aB}}$ & $6.57 \pm 0.06^{\mathrm{aBC}}$ & $6.46 \pm 0.04 \mathrm{aCD}$ & $6.23 \pm 0.04^{\mathrm{aE}}$ & $6.37 \pm 0.03 \mathrm{aDE}$ \\
\hline Ethylene & $6.70 \pm 0.04^{\mathrm{aA}}$ & $6.59 \pm 0.02^{\mathrm{aAB}}$ & $6.51 \pm 0.04 \mathrm{aBC}$ & $6.33 \pm 0.08$ abD & $6.30 \pm 0.02^{\mathrm{aD}}$ & $6.34 \pm 0.03 \mathrm{aCD}$ \\
\hline 1-MCP & $10.62 \pm 0.81^{\mathrm{aA}}$ & $10.46 \pm 0.62^{\mathrm{aA}}$ & $9.28 \pm 0.79^{\mathrm{aA}}$ & $10.50 \pm 0.73^{\mathrm{aA}}$ & $11.82 \pm 0.79^{\mathrm{aA}}$ & $9.50 \pm 1.21^{\mathrm{aA}}$ \\
\hline $\mathrm{AOA}$ & $10.62 \pm 0.81^{\mathrm{aA}}$ & $10.82 \pm 0.46^{\mathrm{aA}}$ & $10.64 \pm 0.49^{\mathrm{aA}}$ & $8.84 \pm 0.16^{\mathrm{aA}}$ & $10.72 \pm 0.82^{\mathrm{aA}}$ & $9.64 \pm 0.48^{\mathrm{aA}}$ \\
\hline \multirow[t]{2}{*}{ Ethylene } & $10.62 \pm 0.81_{\mathrm{aA}}^{\mathrm{aA}}$ & $11.38 \pm 0.73^{\mathrm{aA}}$ & $10.88 \pm 0.47^{\mathrm{aA}}$ & $10.36 \pm 0.78^{\mathrm{aA}}$ & $12.00 \pm 0.89^{\mathrm{aA}}$ & $9.70 \pm 0.82^{\mathrm{aA}}$ \\
\hline & \multicolumn{6}{|c|}{ Titratable acidity } \\
\hline \multirow[t]{2}{*}{ Ethylene } & $0.19 \pm 0.02^{\mathrm{aA}}$ & $0.18 \pm 0.01^{\mathrm{aA}}$ & $0.19 \pm 0.01^{\mathrm{aA}}$ & $0.17 \pm 0.01^{\mathrm{aA}}$ & $0.18 \pm 0.02^{\mathrm{aA}}$ & $0.17 \pm 0.01^{\mathrm{bA}}$ \\
\hline & \multicolumn{6}{|c|}{ SS/TA ratio } \\
\hline Control & $55.94 \pm 5.96^{\mathrm{aA}^{*}}$ & $67.08 \pm 9.12^{\mathrm{aAB}}$ & $58.97 \pm 4.13^{\mathrm{aAB}}$ & $53.10 \pm 5.33^{\mathrm{aAB}}$ & $51.91 \pm 5.15^{\mathrm{aAB}}$ & $41.78 \pm 9.12^{\mathrm{aB}}$ \\
\hline 1-MCP & $55.94 \pm 5.96^{\mathrm{aA}}$ & $69.29 \pm 6.58^{\mathrm{aAB}}$ & $60.29 \pm 5.46^{\mathrm{aAB}}$ & $60.16 \pm 6.31^{\mathrm{aAB}}$ & $50.67 \pm 5.02^{\mathrm{aAB}}$ & $43.65 \pm 3.26^{\mathrm{aB}}$ \\
\hline $\mathrm{AOA}$ & $55.94 \pm 5.96^{\mathrm{aA}}$ & $61.69 \pm 2.99^{\mathrm{aA}}$ & $56.85 \pm 1.93^{\mathrm{aA}}$ & $53.35 \pm 3.95^{\mathrm{aA}}$ & $57.54 \pm 2.96^{\mathrm{aA}}$ & $47.02 \pm 3.03^{\mathrm{aA}}$ \\
\hline Ethylene & $55.94 \pm 5.96^{\mathrm{aA}}$ & $61.85 \pm 3.89^{\mathrm{aA}}$ & $57.69 \pm 1.32^{\mathrm{aA}}$ & $60.64 \pm 6.63^{\mathrm{aA}}$ & $61.44 \pm 5.76^{\mathrm{aA}}$ & $56.48 \pm 3.86^{\mathrm{aA}}$ \\
\hline
\end{tabular}

${ }^{*}$ Means followed by the same lowercase letter don't differ from each other in the same column, and means followed by the same capital letter don't differ from each other on the same line. Means were compared by Tukey test $(\mathrm{p}<0.5)$. The standard error of the mean is shown $(\mathrm{n}=5)$. 
Reducing sugars interact with amino acids during the frying and give rise to Maillard reaction products, which lead to non-enzymatic browning and flavour formation. This process is initiated when the carbonyl group of the reducing sugar reacts with an amino group of free amino acids. The initial products of the reaction are $\mathrm{N}$-glycosylamines or $\mathrm{N}$-fructosylamines, which give rise to intermediate products and final heterocyclization and polymerization (Liu et al., 2019). Unlike potatoes, sweet potatoes contain low asparagine levels and high reducing sugar levels, therefore, asparagine is probably a limiting factor in the acrylamide formation in fried sweet potato chips (Truong et al., 2014).
The same authors showed values of acrylamide $<100$ ng.g ${ }^{-1}$ which is lower than the French fries.

In Table 3, you can see that $\mathrm{pH}$ averages varied among the treatments only at 21 days of storage, and the control shows the lowest average of 6.18). The $\mathrm{pH}$ averages decreased along the storage in all evaluated treatments. Reductions in $\mathrm{pH}$ are related to increases in organic acid concentration as a product of pectin methylesterase activity during storage, which tends to decrease the $\mathrm{pH}$ value (Costa \& Balbino, 2002).

Soluble solids did not differ among treatments or length of storage (Table 3 ). And in titratable acidity evaluation, there were no variations between treatments, but in control
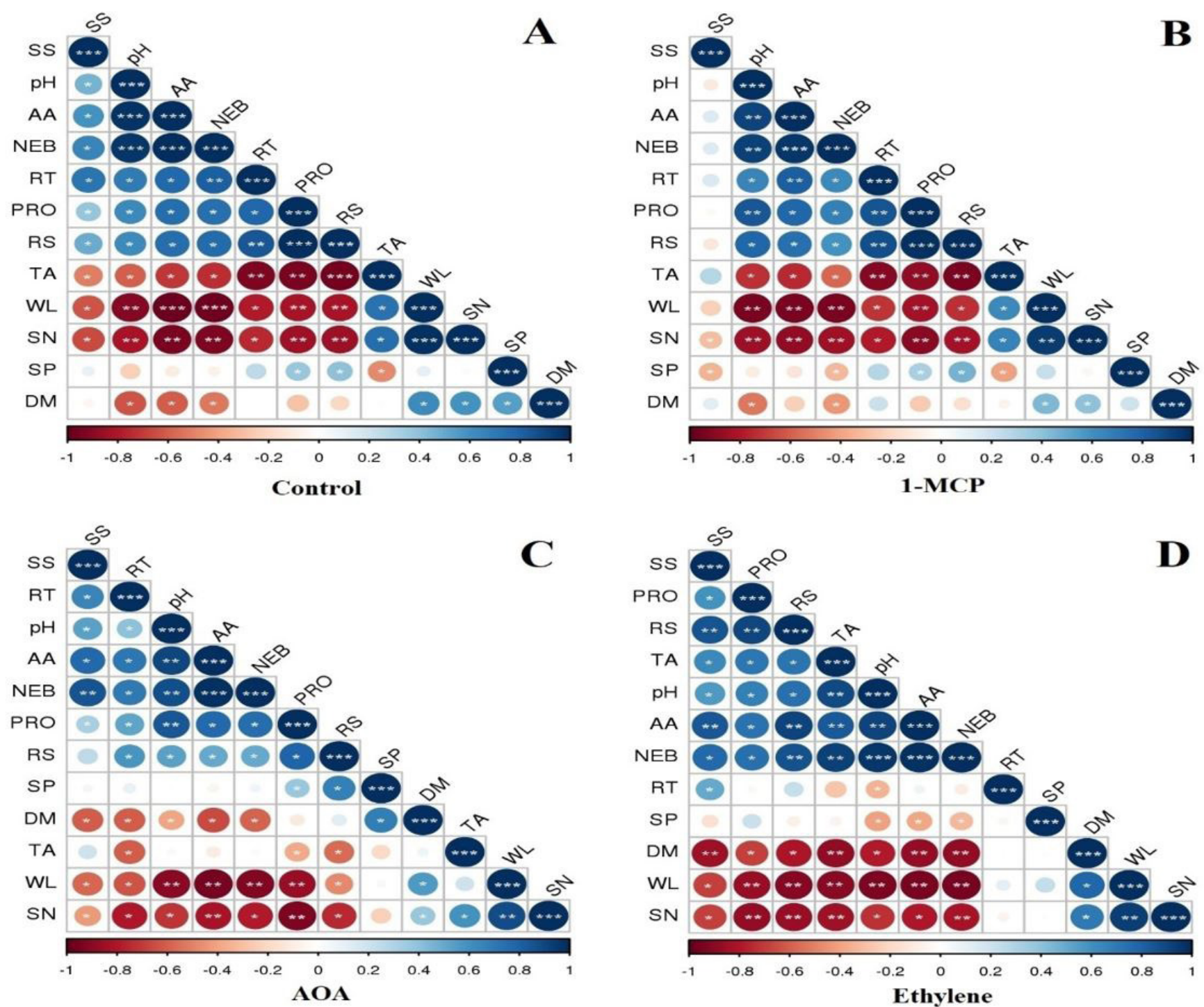

Figure 2. Heat map of Pearson's correlation between weight loss (WL), sprouts number (SN), dry matter content (DM), non-enzymatic browning (NEB), protein content (PRO), soluble phenols (SP), reducing sugars (RS), amino acids content (AA), pH, soluble solids (SS), titratable acidity (TA), SS/TA ratio (RT) in sweet potato roots (BRS Rubissol) stored at $25^{\circ} \mathrm{C}$, according the treatments: control (A), 1-MCP (B), AOA (C) and Ethylene (D). ${ }^{*}$ The colors of the bars indicate the nature of the correlation, where 1 consists of a perfectly positive correlation (dark blue) and -1 means a perfectly negative correlation (dark red). Strong correlations are indicated by large circles, while weak correlations are indicated by small circles. Asterisks within the circle are P-values. ${ }^{* * *},{ }^{* *}$, and ${ }^{*}$ indicate significance at $0.01,1$ and $5 \%$, respectively). 
and 1-MCP treatment, there were increases during the storage time (Table 3 ). The maintenance of soluble solids and titratable acidity during storage are related to the maintenance of the physicochemical quality of roots for fresh consumption and processing.

Soluble solids content is used as an indirect measure of sugars contents in plant materials (Lima et al., 2015) and titratable acidity quantifies the organic acids presents in the food products, which influence the taste, flavor, color, stability and quality maintenance in fresh and processed products (Feltran et al., 2004).

SS/TA ratio did not differ among treatments, but in control and 1-MCP treatment, there were decreases during the storage (Table 3). In order to maintain processing quality, is necessary meet the quality minimum requirements to trade these products, including the low presence of injuries and defects, the minimum content of total soluble solids, minimum total soluble solids/ total titratable acidity ratio (TSS/TTA) and consumer demand (Suszek et al., 2017).

Pearson's correlation coefficients are represented in the heat map of Figure 2. Regarding the evaluated treatments, you can see that have some characteristics in common, mainly the strong positive correlation between AA and NEB ( $\mathrm{P}>0,001 \%)$. Other characteristics common to all treatments are that the $\mathrm{pH}$ variable correlated positively with $\mathrm{AA}$ and NEB; and WL correlated positively with $\mathrm{SN}(\mathrm{p}>1 \%)$. In addition, the variable WL correlated negatively with NEB, AA, PRO, and pH; and PRO correlated negatively with $\mathrm{SN}(\mathrm{p}>1 \%)$.

It is noted that the sprouting process increases weight loss and root sprouting during storage, consuming mainly the protein reserves for sprout growth, decreasing the amino acid contents, and reducing the $\mathrm{pH}$ values. In this case, reducing sugars contents on its own did not show a significant correlation with chips color after frying. On the other hand, the reductions during storage time in total amino acids content correlated with the color of the fried chip (Lima et al., 2020). Therefore, the sprouting process changed this complex relationship between the concentrations of reducing sugars, amino acids, and the formation of acrylamide, and the total amino acid content seems to be the over-riding factor.

\section{Conclusions}

The sweet potato roots cv. BRS Rubissol present good potential for processing fried chips. 1-MCP and AOA treatments reduced the root sprouting, physical-chemical quality was maintained in all evaluated treatments, and the sweet potato chip color after frying showed reductions in all treatments during storage time. Since the sprouting process compromises the storage of roots, AOA and 1-MCP treatments would be interesting in extending the shelf-life of roots and improve the processing potential.

\section{Acknowledgements}

This study was financed in part by the National Council for Scientific and Technological Development (CNPq).

\section{References}

Abbasi, K. S., Masud, T., Ali, S., Khan, S. U., Mahmood, T., \& Qayyum, A. (2015). Sugar-Starch metabolism and antioxidant potential in potato tubers in response to different antisprouting agents during storage. Potato Research, 58(4), 361-375. http://dx.doi.org/10.1007/s11540-015-9306-4.

Amoah, R. S., Landahl, S., \& Terry, L. A. (2016). The timing of exogenous ethylene supplementation differentially affects stored sweet potato. Postharvest Biology and Technology, 120, 92-102. http://dx.doi. org/10.1016/j.postharvbio.2016.05.013.

Association of Official Analytical Chemists - AOAC. (2012). Official methods of analysis of the Association of Official Analytical Chemists (9th ed.). Gaithersburg, Maryland: AOAC International.

Bradford, M. M. (1976). A rapid and sensitive method for the quantitation of microgram quantities of protein utilizing the principle of proteindye binding. Analytical Biochemistry, 72(1-2), 248-254. http://dx.doi. org/10.1016/0003-2697(76)90527-3. PMid:942051.

Caetano, P. K., Mariano-Nasser, F. A. C., Mendonça, V. Z., Furlaneto, K. A., Daiuto, E. R., \& Vieites, R. L. (2018). Physiochemical and sensory characteristics of sweet potato chips undergoing different cooking methods. Food Science and Technology (Campinas), 38(3), 434-440. http://dx.doi.org/10.1590/1678-457x.08217.

Castro, L. A. S., \& Becker, A. (2011). Batata-doce BRS Rubissol (2 p.). Pelotas: Embrapa Clima Temperado.

Cheema, M. U. A., Rees, D., Colgan, R. J., Taylor, M., \& Westby, A. (2013). The effects of ethylene, 1-MCP and AVG on sprouting in sweetpotato roots. Postharvest Biology and Technology, 85, 89-93. http://dx.doi.org/10.1016/j.postharvbio.2013.05.001.

Costa, A. F. S., \& Balbino, J. M. S. (2002). Características da fruta para exportação e normas de qualidade. In M. I. S. Folegatti \& F. C. A. U. Matsuura. Mamão: pós-colheita (Chap. 2, pp. 12-18, Série Frutas do Brasil, No. 21). Brasília: Embrapa Informação Tecnológica.

Dubois, M., Van Den Broeck, L., \& Inzé, D. (2018). The Pivotal Role of Ethylene in Plant Growth. Trends in Plant Science, 23(4), 311-323. http://dx.doi.org/10.1016/j.tplants.2018.01.003. PMid:29428350.

Food and Agriculture Organization - FAOSTAT (2016). Production quantity [Internet]. Food and Agricultural Organization. Retrieved from http://www.fao.org/faostat/en/\#data/QC.

Feltran, J. C., Lemos, L. B., \& Vieites, R. L. (2004). Technological quality and utilization of potato tubers. Scientia Agrícola, 61(6), 593-597. http://dx.doi.org/10.1590/S0103-90162004000600006.

Ferreira, D. F. (2011). Sisvar: a computer statistical analysis system. Ciência e Agrotecnologia, 35(6), 1039-1042. http://dx.doi.org/10.1590/ S1413-70542011000600001.

Fu, L., Xu, B. T., Xu, X. R., Qin, X. S., Gan, R. Y., \& Li, H. B. (2010). Antioxidant capacities and total phenolic contents of 56 wild fruits from South China. Molecules (Basel, Switzerland), 15(12), 8602-8617. http://dx.doi.org/10.3390/molecules15128602. PMid:21116229.

Gonçalves, C., Rodriguez-Jasso, R. M., Gomes, N., Teixeira, J. A., \& Belo, I. (2010). Adaptation of dinitrosalicylic acid method to microtiter plates. Analytical Methods, 2(12), 2046-2048. http:// dx.doi.org/10.1039/c0ay00525h.

Lima, P. C. C., Santos, M. N. S., Araujo, F. F., Tello, J. P. J., \& Finger, F. F. (2019). Sprouting and metabolism of sweet potatoes roots cv. BRS Rubissol during storage. Agrária, 14(3), e6204. http://dx.doi. org/10.5039/agraria.v14i3a6204.

Lima, P. C. C., Santos, M. N. S., Araújo, N. O., \& Finger, F. F. (2020). Does sprout control treatments affect qualitative interactions analysis on fried chips of sweet potatoes cv. BRS Rubissol? International 
Journal of Development Research, 10(7), 38040-38041. http://dx.doi. org/10.37118/ijdr.19379.07.2020.

Lima, T. L. S., Cavalcante, C. L., Sousa, D. G., Silva, P. H. A., \& Andrade Sobrinho, L. G. (2015). Avaliação da composição físico-química de polpas de frutas comercializadas em cinco cidades do alto sertão paraibano. Revista Verde, 10(2), 49-55. http://dx.doi.org/10.18378/ rvads.v10i2.3378.

Liu, P., Lu, X., Li, N., Zheng, Z., Zhao, R., Tang, X., \& Qiao, X. (2019). Effects and mechanism of free amino acids on browning in the processing of black garlic. Journal of the Science of Food and Agriculture, 99(10), 4670-4676. http://dx.doi.org/10.1002/jsfa.9707. PMid:30906992.

Mani, F., Bettaieb, T., Doudech, N., \& Hannachi, C. (2014). Physiological mechanisms for potato dormancy release and sprouting: a review. African Crop Science Journal, 22(2), 155-174. Retrieved from https:// www.ajol.info/index.php/acsj/article/viewFile/104945/94994

Mathooko, F. M., Tsunashima, Y., Owino, W. Z. O., Kubo, Y., \& Inaba, A. (2001). Regulation of genes encoding ethylene biosynthesis enzymes in peach (Prunus persica L.) fruit by carbon dioxide and 1-methylcyclopropene. Postharvest Biology and Technology, 21(3), 265-281. http://dx.doi.org/10.1016/S0925-5214(00)00158-7.

Meher, C., Mishra, B. K., Nayak, P., \& Singh, V. (2015). Effect of predrying and frying kinetics of sweet potato (Ipomoea batatas L.). The Bioscan, 10(2), 521-525. http://dx.doi.org/10.1111/ECOSCAN.

Motsa, N. M., Modi, A. T., \& Mabhaudhi, T. (2015). Sweet potato (Ipomoea batatas L.) as drought tolerant and food security crop. South African Journal of Science, 111(11-12), 1-8. http://dx.doi. org/10.17159/sajs.2015/20140252.

Mu, T. H., Tan, S. S., \& Xue, Y. L. (2009). The amino acid composition, solubility and emulsifying properties of sweet potato protein. Food Chemistry, 112(4), 1002-1005. http://dx.doi.org/10.1016/j. foodchem.2008.07.012.

$\mathrm{Mu}$, T.-H., \& Li, P.-G. (2019). Sweet potato: origin and production. In T-H. Mu \& J. Singh (Eds.), Sweet potato: chemistry, processing and nutrition (Chap. 2, pp. 5-25). London: Academic Press. http://dx.doi. org/10.1016/B978-0-12-813637-9.00002-8

Mu, T.-H., Sun, H.-N., \& Ma, M.-S. (2019). Sweet potato snack foods. In T-H. Mu \& J. Singh (Eds.), Sweet potato: chemistry, processing and nutrition (Chap. 11, pp. 303-324). London: Academic Press. http:// dx.doi.org/10.1016/B978-0-12-813637-9.00011-9

Müller, D. R., Bsognin, D. S., Andriolo, J. L., Morin, G. R., Jr., \& Gnocato, F. S. (2009). Expressão dos caracteres e seleção de clones de batata nas condições de cultivo de primavera e outono. Ciência Rural, 39, 1237-1334. http://dx.doi.org/10.1590/ S0103-84782009005000078.

Muttucumaru, N., Powers, S. J., Elmore, J. S., Dodson, A., Briddon, A., Mottram, D. S., \& Halford, N. G. (2017). Acrylamide-forming potential of potatoes grown at different locations, and the ratio of free asparagine to reducing sugars at which free asparagine becomes a limiting factor for acrylamide formation. Food Chemistry, 220, 76-86. http://dx.doi.org/10.1016/j.foodchem.2016.09.199. PMid:27855938.

Orlien, V, \& Bolumar, T. (2019). Biochemical and nutritional changes during food processing and storage. Foods, 8(10), 494. https://doi. org/10.3390/foods8100494.

Santos, C. M. R., Menezes, N. L., \& Villela, F. A. (2005). Modificações fisiológicas e bioquímicas em sementes de feijão no armazenamento. Revista Brasileira de Sementes, 27(1), 104-114. http://dx.doi. org/10.1590/S0101-31222005000100013.

Suszek, G., Souza, E. G., Nóbrega, L. H. P., Pacheco, F., \& Silva, C. T. A. C. (2017). Use of yield and total soluble solids / total titatrable acidity ratio in Orange on group definition for standard dris. Revista Brasileira de Fruticultura, 39(4), 1-9. http://dx.doi.org/10.1590/010029452017876

Truong, V. D., Pascua, Y. T., Reynolds, R., Thompson, R. L., Palazoğlu, T. K., Mogol, B. A., \& Gökmen, V. (2014). Processing treatments for mitigating acrylamide formation in sweetpotato French fries. Journal of Agricultural and Food Chemistry, 62(Pt 1), 310-316. http:// dx.doi.org/10.1021/jf404290v. PMid:24328312.

Van de Poel, B., Smet, D., \& Van Der Straeten, D. (2015). Ethylene and hormonal cross talk in vegetative growth and development. Plant Physiology, 169(1), 61-72. http://dx.doi.org/10.1104/pp.15.00724. PMid:26232489.

Wang, S., Nie, S. P., \& Zhu, F. (2016). Chemical constituents and health effects of sweet potato. Food Research International, 89(1), 90-116. http://dx.doi.org/10.1016/j.foodres.2016.08.032. PMid:28460992.

Watkins, C. B. (2006). The use of 1-methylcyclopropene (1-MCP) on fruits and vegetables. Biotechnology Advances, 24(4), 389-409. http://dx.doi.org/10.1016/j.biotechadv.2006.01.005. PMid:16530376.

Wei, T., Simko, V., Levy, M., Xie, Y., Jin, Y., \& Zemla, J. (2017). Package 'corrplot'. Package 'corrplot'. The Statistician, 56, 316-324.

Xu, F. X., Liu, S. Y., \& Feng, X. Q. (2016). Effect of 1-octylcyclopropene on physiological responses and expression of ethylene receptors gene in harvested tomato fruit. Postharvest Biology and Technology, 117, 30-37. http://dx.doi.org/10.1016/j.postharvbio.2015.12.016.

Yemm, E. W., Cocking, E. C., \& Ricketts, R. E. (1955). The determination of amino-acids with ninhydrin. Analyst (London), 80(948), 209-214. http://dx.doi.org/10.1039/an9558000209. 